\title{
Potential microbial functional activity along a Posidonia oceanica soil profile
}

\author{
Nerea Piñeiro-Juncal ${ }^{1,2, *}$, Miguel Ángel Mateo ${ }^{2}$, Marianne Holmer $^{3}$, \\ Antonio Martínez-Cortizas ${ }^{1}$ \\ ${ }^{1}$ Departamento de Edafoloxía e Química Agrícola, Universidade de Santiago de Compostela, \\ 15782 Santiago de Compostela, Spain \\ ${ }^{2}$ Centro de Estudios Avanzados de Blanes (CEAB), 17300 - Blanes, Girona, Spain \\ ${ }^{3}$ Department of Biology, University of Southern Denmark, 5230 Odense M, Denmark
}

\begin{abstract}
Among the ecosystem services provided by the seagrass Posidonia oceanica, its role as a carbon sink has received growing attention during the last decade. The sequestration and stabilization of carbon in soils are tightly linked to the activity of its microbial community. EcoPlates (Biolog) comprise a semi-quantitative tool for the assessment of microbial functional activity that generates profiles of microbial carbon source utilization. In this study, the aerobic and anaerobic carbon consumption in a healthy $P$. oceanica meadow was compared throughout depths down to $130 \mathrm{~cm}$. After $11 \mathrm{~d}$, the average well color development, Shannon-Wiener diversity index $\left(H^{\prime}\right)$, and kinetics of carbon consumption were assessed. Both the aerobic and anaerobic metabolisms showed carbon consumption at all depths. Color observations indicated that carbohydrates, amino acids and polymers were mainly consumed, while carboxylic acids, amines and miscellaneous compounds presented low or no consumption at all. Carbon consumption kinetics were similar for both metabolisms. The results suggest a pronounced stratification of the microbial community controlled by oxygen availability. Despite the higher aerobic metabolism in the top $40 \mathrm{~cm}$, the anaerobic metabolism was dominant, supporting high sequestration of carbon in $P$. oceanica meadows.
\end{abstract}

KEY WORDS: Biolog ${ }^{\circledR}$ EcoPlates ${ }^{\mathrm{TM}} \cdot$ Microbial activity $\cdot$ Aerobic metabolism $\cdot$ Anaerobic metabolism $\cdot$ Long-term carbon sink $\cdot$ Posidonia oceanica

\section{INTRODUCTION}

Posidonia oceanica (L.) Delile is an aquatic macrophyte, endemic to the Mediterranean Sea, forming extensive meadows down to $40 \mathrm{~m}$ depth (Ballesta et al. 2000), and covering from 25000 to $50000 \mathrm{~km}^{2}$ (Pasqualini et al. 1998). The meadows grow in height by accretion due to the sedimentation of particles, enhanced by the macrophyte canopy (Gacia \& Duarte 2001, Marbá et al. 2006). P. oceanica, like other seagrasses, increases the carbon content of the substrate (Mateo \& Romero 1997) and its bacterial diversity (López et al. 1995, García-Martínez et al. 2009). These meadows have been recognized as key coastal ecosystems (Campagne et al. 2015), acting as filters and sinks of natural particles and pollutants (Richir et al. 2013, Serrano et al. 2013). Their efficiency as filters of pollutants is much higher than for average macrophytes (Vassallo et al. 2013), and due to this capacity, $P$. oceanica is widely used as a bioindicator (Pergent-Martini et al. 2005) of water quality (Foden \& Brazier 2007, Gobert et al. 2009) and of human impact in coastal ecosystems (Balata et al. 2008, Luy et al. 2012, Richir \& Gobert 2014).

The different species of the Posidonia genus, distributed along the Mediterranean and the Australian coasts, stimulate the deposition of sediments chronologically, forming deep soils (or mats) with a high 
potential to serve as environmental archives of the Holocene (Ancora et al. 2004, Tranchina et al. 2005, López-Sáez et al. 2009, Tovar-Sánchez et al. 2010, Serrano et al. 2013, 2016, López-Merino et al. 2015). The organic matter can be trapped on the soil over millennia due to the anoxic conditions that prevent its fast remineralization (Canfield 1994), making the meadow a significant global carbon sink (Mateo et al. 2006, De Falco et al. 2011).

Microorganisms play a major role in carbon stabilization and degradation, determining how and how much carbon accumulates. Carbon degradation rates in marine sediments are usually associated with redox conditions, i.e. the availability of electron acceptors coupled with their corresponding microbial metabolism (Fenchel et al. 1998, Thamdrup et al. 2000, Llobet-Brossa et al. 2002). The microbial decomposition of organic matter in marine sediments in aerobic conditions is much faster than in anaerobic conditions (Kristensen \& Holmer 2001), and leads to a more complete mineralization of a wide range of carbon sources. Anaerobic microorganisms usually need a more complex bacterial food web working stepwise (Fenchel et al. 1998). Furthermore, they are inefficient in mineralizing structural molecules such as lignin, which is usually preserved in anoxic environments (Kristensen et al. 1995). Bacterial activity in seagrass meadows has been shown to have a positive correlation with seagrass production (Danovaro et al. 1994, López et al. 1995, Glazebrook et al. 1996, Smith et al. 2004) that can shift to a negative correlation when nutrient availability is low (Danovaro et al. 1994, López et al. 1998, Holmer et al. 2003, Smith et al. 2004). Another study focusing on the decomposition of the organic matter in a P. oceanica mat found overall low remineralization rates and a decrease in nutrients (i.e. nitrogen) with depth in the mat (Pedersen et al. 2011).

Genetic tools allow the study of uncultivated microorganisms, but generate a large amount of information, which is difficult to process and not necessarily related with the carbon consumption or the metabolism of the microbial community (Rodríguez-Valera 2004, Sørensen et al. 2007). The use of Biolog ${ }^{\circledR}$ EcoPlates $^{\mathrm{TM}}$ is a semi-quantitative method developed to characterize microbial functional activity by measuring the respiration of different carbon sources divided into 6 guilds: carbohydrates, polymers, carboxylic acids, amino acids, amines and miscellaneous compounds. Respiration of the microbial community is revealed by the reduction of a tetrazolium dye that is included with the carbon source. EcoPlates have been used to characterize microbial activity in Posi- donia spp. mats, in the water column above them (Richir et al. 2012) and in the soil (Säwström et al. 2016), but only under aerobic conditions. As the mat is a highly reduced environment, experiments comparing both aerobic and anaerobic activity may provide important information on the role of the 2 metabolisms. EcoPlates have also been used to measure aerobic activity in rivers, lakes and soils, comparing differences in potential carbon consumption seasonally and geographically (Christian \& Lind 2007, Lyons \& Dobbs 2012, Pérez Rodríguez \& Martínez Cortizas 2014, Freixa et al. 2016). Christian \& Lind (2007), working in a seasonally stratified lake, found a correlation between the consumed carbon sources, seasonal variations and temperature, $\mathrm{O}_{2}$ diffusion and redox potential. The same authors successfully used EcoPlates to measure anaerobic activity in water samples, the anaerobic communities also being affected by seasonal variations (Christian \& Lind 2006).

In the present study, we used EcoPlates to assess the patterns of distribution of bacterial activity within the mat. Although the compounds provided are generic and not specifically tailored for the microbiota inhabiting $P$. oceanica mats, the diversity of habitats where EcoPlates have been used should allow a richer and more direct comparison across environments. Similarly, as a first step, it seems sensible to use the commercially available substrates supplied in the EcoPlates for a preliminary exploration of aerobic and anaerobic activity in this new habitat. To this end, we incubated mat samples, obtained along a $1.30 \mathrm{~m}$ mat core of $P$. oceanica, under anaerobic and aerobic conditions (the first time EcoPlates have been used to measure anaerobic activity in sediment samples). The implications of these microbial patterns for carbon degradation and preservation in the soil are discussed.

\section{MATERIALS AND METHODS}

\section{Sampling site and field work}

A core of Posidonia oceanica soil was taken in Portlligat Bay, Girona, Spain $\left(42^{\circ} 17.454^{\prime} \mathrm{N}, 3^{\circ} 17\right.$. $513^{\prime} \mathrm{E}$ ). Around $69 \%$ of the bay is covered by well preserved $P$. oceanica meadows growing in medium to coarse sand (Lo Iocano et al. 2008). The bay connects to the sea by a $213 \mathrm{~m}$ wide opening to the North East. The core was collected on 29 October, when $P$. oceanica meadows have low rates of productivity due to the loss of leaves (Alcoverro et al. 2001). Water temperatures were still high at this time of the year, 
and due to the shallow and sheltered nature of the bay. It is therefore to be expected that the system had particularly favorable conditions for high rates of bacterial activity resulting from the combination of high organic matter input (leaf litter) and high temperatures (Mateo et al. 2006).

Sampling was done by SCUBA diving, by manually hammering and rotating a PVC corer $(160 \mathrm{~cm}$ long, i.d. $7.5 \mathrm{~cm}$ ) into the soil. A core catcher was fitted at the bottom of the corer to avoid the loss of material during the extraction. The corer penetrated $146 \mathrm{~cm}$ into the soil but the length of core retrieved was $91 \mathrm{~cm}$. Assuming the core catcher worked efficiently and that no material was released during retrieval, this yields a core compression of $38 \%$, a normal value for this coring method (Glew et al. 2001).

The core was sealed with stoppers, taped at both ends and transported to the laboratory under cold conditions within $2 \mathrm{~h}$ after collection. In the laboratory, it was cut longitudinally into 2 halves using a ceramic knife for the inner core to avoid metal contamination. Both halves (referred to as hemi-cores) were then sealed and stored at $5^{\circ} \mathrm{C}$ in darkness for $2 \mathrm{~d}$ until processing.

\section{Analysis of microbial functional activity}

The bottom $8 \mathrm{~cm}$ were discarded, resulting in a remaining core length of $83 \mathrm{~cm}$. Core-shortening (compression) was corrected by applying a logarithmic function to the length measured in the laboratory to approximate it to the field length, as described by Serrano et al. (2012), resulting in a $131 \mathrm{~cm}$ soil profile. The labels of the samples in this study refer to the decompressed depth.

\section{EcoPlate aerobic incubations}

In essence, the protocol performed for aerobic and anaerobic incubations of the samples is a modification of the method applied by Pérez-Rodríguez \& Martínez-Cortizas (2014) for peat under aerobic conditions, adapted to marine sediment samples and anaerobic conditions through the use of a nitrogen chamber and artificial seawater.

Each hemi-core was cut into $2 \mathrm{~cm}$ sections and subsampled for microbial analysis in 15 layers (see Fig. 2 for sample distribution). Because $\mathrm{Ca}^{+2}$ concentrations greater than $100 \mathrm{ppm}$ can induce false positives in EcoPlates (Pierce et al. 2014), 1 sample was taken from each half core to determine the Ca content (see below).
All materials used were sterilized at $120^{\circ} \mathrm{C}$ for $1 \mathrm{~h}$, to avoid contamination between samples. A $4 \mathrm{~cm}^{3}$ sample was taken from each section using a sterile polycarbonate cylinder, and stored in $50 \mathrm{ml}$ falcon tubes with $30 \mathrm{ml}$ of sterilized artificial seawater (formula: $25.9 \mathrm{~g} \mathrm{NaCl}+13.6 \mathrm{~g} \mathrm{MgCl}_{2} \cdot 6 \mathrm{H}_{2} \mathrm{O}+4.14 \mathrm{~g}$ $\mathrm{NaSO}_{4}$ in $1000 \mathrm{ml}$ of $\mathrm{H}_{2} \mathrm{O}$ ). The tubes were vigorously shaken at room temperature for $3 \mathrm{~d}$ to suspend and activate the microorganisms after the cold storage period. The suspensions were then filtered through 15 to $20 \mu \mathrm{m}$ filters (Albet140) and used to inoculate the EcoPlates. Each well was inoculated with $100 \mu \mathrm{l}$ suspension using a multichannel micropipette and read right away to get the blank (T0). The plates were then incubated at $26^{\circ} \mathrm{C}$ for $11 \mathrm{~d}$. The plates were read twice a day during the first $5 \mathrm{~d}$ and once a day after that (T1 to T15).

Every plate has 96 wells containing 31 different carbon sources (2 amines, 3 miscellaneous compounds, 4 polymers, 7 carbohydrates, 9 carboxylic acids and 6 amino acids; see Fig. 1) in triplicate and a blank. Each well contains a minimum growth medium and a tetrazolium dye that develops color when the microorganisms reduce the substrate. The absorbance was read at $590 \mathrm{~nm}$ in a spectrophotometer (Model 680, Bio-Rad Laboratories).

The Ca concentration was analyzed after filtration of the 2 samples by atomic absorption, and showed values lower than the limit $\left(<100\right.$ ppm $\mathrm{Ca}_{\text {; }}$ data not shown).

\section{EcoPlate anaerobic incubations}

Subsampling and replication was the same in the anaerobic and aerobic incubations, except that the extraction, filtration and inoculation were performed in a nitrogen atmosphere (chamber Cole Parmer MO: SL 34790-00). The artificial seawater was bubbled with nitrogen before being used for the experiment within the chamber (Christian \& Lind 2006). The tubes and inoculated plates were sealed with parafilm before removing them from the chamber. The incubation and the readings were as for the aerobic incubations, keeping the anaerobic samples sealed with parafilm to avoid the diffusion of oxygen into them.

EcoPlate performance under anaerobic conditions

To check the seal effectivity on the plates, we placed dry silica gel within a plate sealed in the 


\begin{tabular}{|c|c|c|c|}
\hline $\begin{array}{l}\text { A1 } \\
\text { Water }\end{array}$ & $\begin{array}{l}\text { A2 } \\
\text { B-Methyl-D- } \\
\text { Glucoside } \\
\text { Cbh }\end{array}$ & \begin{tabular}{|l|} 
A3 \\
D-Galactonic \\
Acid \\
$\gamma$-Lactone \\
Cb A \\
\end{tabular} & $\begin{array}{l}\text { A4 } \\
\text { L-Arginine } \\
\text { Am A }\end{array}$ \\
\hline $\begin{array}{l}\text { B1 } \\
\text { Pyruvic Acid } \\
\text { Methyl Ester } \\
\text { Misc }\end{array}$ & $\begin{array}{l}\text { B2 } \\
\text { D-Xylose } \\
\text { Cbh }\end{array}$ & $\begin{array}{l}\text { B3 } \\
\text { D- } \\
\text { Galacturonic } \\
\text { Acid } \\
\text { Cb A }\end{array}$ & $\begin{array}{l}\text { B4 } \\
\text { L-Asparagine } \\
\text { Am A }\end{array}$ \\
\hline $\begin{array}{l}\text { C1 } \\
\text { Tween } 40 \\
\text { Pol }\end{array}$ & $\begin{array}{l}\text { C2 } \\
\text { i-Erythritol } \\
\text { Cbh }\end{array}$ & $\begin{array}{l}\text { C3 } \\
\text { 2-Hydroxy } \\
\text { Benzoic Acid } \\
\text { Cb A }\end{array}$ & $\begin{array}{l}\text { C4 } \\
\text { L- } \\
\text { Phenylalanine } \\
\text { Am A }\end{array}$ \\
\hline $\begin{array}{l}\text { D1 } \\
\text { Tween } 80 \\
\text { Pol }\end{array}$ & $\begin{array}{l}\text { D2 } \\
\text { D-Mannitol } \\
\text { Cbh }\end{array}$ & $\begin{array}{l}\text { D3 } \\
\text { 4-Hydroxy } \\
\text { Benzoic Acid } \\
\text { Cb A }\end{array}$ & $\begin{array}{l}\text { D4 } \\
\text { L-Serine } \\
\text { Am A }\end{array}$ \\
\hline $\begin{array}{l}\text { E1 } \\
\alpha- \\
\text { Cyclodextrin } \\
\text { Pol }\end{array}$ & $\begin{array}{l}\text { E2 } \\
\text { N-Acetyl-D- } \\
\text { Glucosamine } \\
\text { Cbh }\end{array}$ & $\begin{array}{l}\text { E3 } \\
\gamma- \\
\text { Hydroxybutyric } \\
\text { Acid } \\
\text { Cb A }\end{array}$ & $\begin{array}{l}\text { E4 } \\
\text { L-Threonine } \\
\text { Am A }\end{array}$ \\
\hline $\begin{array}{l}\text { F1 } \\
\text { Glycogen } \\
\text { Pol }\end{array}$ & $\begin{array}{l}\text { F2 } \\
\text { D- } \\
\text { Glucosaminic } \\
\text { Acid } \\
\text { Cb A } \\
\end{array}$ & $\begin{array}{l}\text { F3 } \\
\text { Itaconic Acid } \\
\text { Cb A }\end{array}$ & $\begin{array}{l}\text { F4 } \\
\text { Glycyl-L- } \\
\text { Glutamic Acid } \\
\text { Am A }\end{array}$ \\
\hline $\begin{array}{l}\text { G1 } \\
\text { D-Cellobiose } \\
\text { Cbh }\end{array}$ & $\begin{array}{l}\text { G2 } \\
\text { Glucose-1- } \\
\text { Phosphate } \\
\text { Misc }\end{array}$ & $\begin{array}{l}\text { G3 } \\
\alpha-\text { Ketobutyric } \\
\text { Acid } \\
\text { Cb A }\end{array}$ & $\begin{array}{l}\text { G4 } \\
\text { Phenylethyl- } \\
\text { amine } \\
\text { Amin }\end{array}$ \\
\hline $\begin{array}{l}\text { H1 } \\
\alpha-D \text {-Lactose } \\
\mathrm{Cbh}\end{array}$ & $\begin{array}{l}\text { H2 } \\
\text { D,L- } \alpha- \\
\text { Glycerol } \\
\text { Phosphate } \\
\text { Misc }\end{array}$ & $\begin{array}{l}\text { H3 } \\
\text { D-Malic Acid } \\
\text { Cb A }\end{array}$ & $\begin{array}{l}\mathrm{H} 4 \\
\text { Putrescine } \\
\text { Amin }\end{array}$ \\
\hline
\end{tabular}

Fig. 1. EcoPlate carbon sources. Pol, polymers; Cbh, carbohydrates; Cb A, carboxylic acids; Misc, miscellaneous compounds; Am A, amino acids; Amin, amines. Modified from the Biolog ${ }^{\circledR}$ technical documentation

same way as the experimental ones. After $1 \mathrm{wk}$, no color change was observed. When the seal was broken, the silica started to change color within the same day, evidencing that the sealing had been effective.

There are no precedents of EcoPlates being used to test sediment microbial activity under anaerobic conditions, nor was the manufacturer's default plan to design this product to be used in different oxic conditions. Hence there is no information available from the manufacturers about their performance under such conditions. Theoretically, it should not depend on which electron acceptor is used by the microorganism. EcoPlates have been reported to work under anaerobic conditions in 2 previous works (Christian
\& Lind 2007) and the results obtained in our experiment match the expected results of anoxic color development. Furthermore, the replicates within each plate for each carbon source and those of the same sample inoculated in different plates showed a coherent color development, confirming they were not driven by random factors.

\section{Numerical procedures}

The data from the EcoPlates was processed using the software $\mathrm{R}$ to obtain the mean of each source in each plate at each time, eliminating values that resulted in coefficients of variation larger than 30. The respective mean absorbance at T0 was subtracted from all mean values to obtain the variation due only to the consumption of the carbon source, not to the initial color of the inoculum. After that, the average well color development (AWCD) was calculated for each sample at T15 using the following equation (Garland \& Mills 1991):

$$
\mathrm{AWCD}=\Sigma\left(R_{i}-C\right) / N
$$

where $R_{i}$ is the color of each well at time $i$ (after blank correction), $C$ is the color development in the blank (A1) and $N$ is the number of carbon sources (31). The AWCD quantifies the metabolism in the aerobic and anaerobic incubations.

The Shannon-Wiener diversity index $\left(H^{\prime}\right)$ was also calculated (Stefanowicz et al. 2010):

$$
H^{\prime}=-\Sigma p_{i}\left(\ln p_{i}\right)
$$

where $p_{i}$ is the average corrected color of each well $i$ divided by the sum of all the wells in the plate.

To compare the metabolisms, a ratio (anaerobic: aerobic, AN:AE) was calculated with the absorbance values at T15 for each carbon guild. Values $<10 \%$ of the maximum absorbance value of the guild were excluded and considered as not consumed to avoid extreme ratio values.

The change in AWCD with time showed 2 distinct phases characterized by a fast (typically T1 to T4-T7) and a slower color development (until T15). The slopes of each phase were calculated to express the rate of microbial activity in the wells.

\section{RESULTS}

The core utilized in this study had a high content of macroscopic plant debris (rhizomes, roots and leaf sheaths) in the upper part $(25 \mathrm{~cm})$ whereas much 


\begin{tabular}{|c|c|c|c|c|c|c|c|c|c|c|c|c|c|c|c|c|c|c|c|c|c|c|c|c|c|c|c|c|c|c|c|c|c|c|}
\hline & & & & & & & & & & & & & & & & & E1 & ILL & & E4 & F1 & & IF3 & If4 & & & G3 & & $\mathrm{H} 1$ & $\mathrm{H} 2$ & H3 & & $\mathrm{WCL}$ & \\
\hline $0^{0-2}$ & & & 1 & 0.4 & 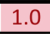 & 1.0 & 8 & 1.5 & & 0.4 & .0 & 0.4 & 0.5 & 1.6 & 0.1 & 1.7 & 1.3 & & 0.2 & 0.5 & & 0.4 & 0.5 & 0.1 & 1.4 & 0.1 & 0.1 & 0.4 & 1.1 & 0.0 & 0.2 & 0. & 54 & \\
\hline $6-9$ & & & & - & 1 & 0.4 & 0.6 & 2.0 & & 0.9 & 0.0 & & 1.3 & 19 & 0.1 & 7 & 16 & 1. & .2 & 1.2 & 2.0 & 0 & $\sigma$ & 2 & .2 & 0.8 & 0.0 & 3 & & 0.1 & 0.7 & 0.8 & 90 & \\
\hline $12-15$ & 0.0 & 1.0 & 0.8 & 0.6 & 1.0 & 1.0 & 0.5 & 2.4 & 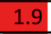 & 0.4 & 0.0 & 2.2 & 1.5 & 2.2 & 0.2 & 1.8 & 1.6 & & 2 & 1.1 & 2.0 & 1 & 0.4 & .0 & ( & 0.1 & 0.0 & 2 & 2.0 & 0. & .2 & 2 & .02 & \\
\hline & 0.0 & 0.0 & & 2 & & & 0.0 & 1.1 & & 0.1 & 0 & 1.4 & 1.1 & & 0.1 & 1.8 & 2.1 & & 2 & 1.1 & 2.1 & .2 & 0.5 & 0.6 & 1.4 & 0.1 & 0.1 & 0.2 & 1.2 & 0. & 0.4 & & so & \\
\hline & & & & .4 & & 1 & 0.5 & 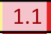 & 1.5 & 1.1 & & & & & 0.2 & .5 & .0 & & 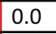 & 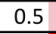 & 1.5 & .1 & 0.6 & 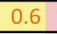 & 1 & - & & 2 & 06 & 0.0 & $\overline{0.4}$ & & & \\
\hline & 0.0 & & & 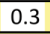 & 8 & & 0.4 & 1.5 & 0.7 & 0.8 & 8 & 1 & 5 & & 0.1 & 1.4 & 0 & 0 & .0 & 5 & 1 & .0 & 0.5 & 0.1 & 1.5 & 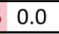 & & & 2.5 & 0. & 1.0 & & & \\
\hline-41 & & & & 8.6 & .0 & 1.1 & 0.8 & 1.6 & $\overline{1.4}$ & 8 & 0.0 & & .0 & 1.3 & 1.0 & 0.7 & 1.9 & 1.1 & .0 & .3 & 1.9 & 0.5 & 0.8 & .5 & 1.0 & 0.0 & 0.1 & 0.6 & 1.7 & 0.0 & 0.4 & & 74 & \\
\hline $44-47$ & 0. & 0 & 0.5 & 0.2 & 1.1 & 5 & 0.4 & 1.2 & 1.0 & .4 & 0 & 0.3 & 0.6 & .0 & 0.3 & 3 & 1.3 & 1.2 & .0 & .1 & 1.6 & 0.7 & 0.3 & .2 & 1.4 & 0.0 & 0.0 & 0.3 & 30.6 & 0.1 & 0.7 & 0.3 & 1.36 &. \\
\hline $50-53$ & 0 & 1 & 0.7 & 0.2 & 1.0 & 0.2 & 0.6 & 0.5 & 0.9 & 0.4 & 0.0 & 0.6 & 0.4 & 6 & 0.3 & 0.8 & 1.4 & .1 & 0.2 & 0.1 & 1.4 & 0.1 & 0.5 & 0.2 & 8.7 & 0.0 & 0. & 0.4 & 0.5 & 0.0 & 0.3 & 0.4 & .46 &. \\
\hline $57-60$ & 0. & 0.8 & 0.6 & 0.3 & 9 & 0.2 & 0.7 & 0.5 & 0.9 & 0.6 & 0.0 & 7 & 3 & .0 & 0.0 & 4 & 0.9 & 0.5 & 2 & 0.1 & 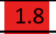 & \begin{tabular}{|l|}
0.0 \\
\end{tabular} & 0.3 & 0.2 & 0.8 & 0.0 & 0.0 & 0.6 & 0.9 & 0.0 & 0.4 & 0.4 & 0.55 & 3.6 \\
\hline-73 & 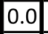 & 0.0 & 0.3 & 0.1 & 1 & 0.3 & 0.5 & .1 & 0.8 & 5 & 0.3 & 5 & 4 & 0 & 0.0 & 0.9 & 1.5 & 1.0 & .0 & 0.3 & 1.5 & 0.0 & 0.4 & 0.0 & 1.4 & 0.0 & 0.0 & 0.1 & 0.8 & 0.0 & 0.3 & 0.1 & 0.49 & 2.5 \\
\hline & 0. & 0.0 & 0.7 & 0.3 & 0.9 & 0.6 & 0.7 & 1.1 & 0.7 & 6 & 0.1 & 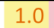 & 1.1 & 4 & 0.2 & 0.8 & 1.6 & 1.5 & 0.0 & 0.6 & 1.9 & 0.7 & 0.5 & 0.4 & 1.0 & 0.0 & 0.0 & 0.5 & 0.7 & 0.0 & 0.3 & 0.8 & .06 & \\
\hline 95 & 0. & D & 0.9 & 0.2 & 0.8 & 0.3 & 0.5 & 0.8 & 1.1 & 5 & 0.0 & ? & 2 & & 0.5 & 1.3 & 1.7 & 1.2 & 0.0 & 0.9 & 1.6 & 0.0 & 0.3 & 0.1 & 1.2 & 0.0 & 0.1 & 1.3 & 31.0 & 0.0 & 0.6 & 0.4 & J.66 & 3.0 \\
\hline $107-11]$ & 0 & 0.0 & 0.6 & 0.0 & 1.1 & 0.4 & 0.2 & 0.7 & 0.7 & 0.7 & 0.1 & & 0.5 & & 0.1 & 0.7 & 1.6 & 1.0 & 0.2 & 0.6 & 1.1 & 0.2 & 0.4 & 0.0 & 0.7 & 0.1 & 0.0 & 4 & 0.0 & 0.0 & 0.5 & U. & .50 & \\
\hline an & 0.0 & 0.3 & 0.6 & 0.3 & 1.0 & 0.1 & 0.5 & 1.2 & 1.11 & .0 & 0 & 1.1 & 0.8 & 1.6 & 0.2 & 1.2 & 6 & 1.4 & 0.1 & 0.5 & 1.7 & .4 & .5 & 0.4 & 2 & 0.1 & 0.0 & 0.4 & 1.1 & 0.0 & 0.5 & 0.49 & 0.66 & 3.1 \\
\hline epth & & & & & & & B= & & & & & & 1 & 22 & D3 & 84 & $=1$ & E2 & & E4 & & $\mathrm{F2}$ & F3 & $F 4$ & G1 & G2 & G3 & G4 & $\mathrm{H} 1$ & $\mathrm{H} 2$ & $\mathrm{H} 3$ & 74 & $\overline{A W C}$ & $H^{\prime \prime}$ \\
\hline |0- & 0. & 1.1 & 8 & 1 & 1.2 & 0.0 & 0.7 & 1.6 & 0.6 & 0.5 & 0.0 & .2 & 1.3 & 5 & 0.0 & 1.2 & 1.3 & 1 & 2 & 1.3 & 1.1 & 0.0 & 0.3 & .7 & 1.0 & 0.5 & 0.0 & 0.0 & 1.2 & 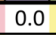 & 0.5 & & 0.74 & 3.1 \\
\hline 6- & 0.0 & 5 & 0.2 & 0 & 0.8 & 0.2 & (c) & .4 & 1.0 & 0.2 & 0 & 0.6 & 0.4 & 7 & 0.1 & 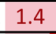 & 4 & 1.4 & I & 1.1 & 2 & 1.1 & 0.2 & 8 & 0 & 0.0 & 0.0 & 0.0 & 0.9 & 0.0 & 0.5 & 0.5 & 1.64 & 3.1 \\
\hline & 0.0 & 0.6 & 7 & 0.9 & 1 & 0.7 & 0.6 & 1.4 & .1 & . & 5 & 9 & 5 & 4 & 0.4 & 1 & 1 & - & - & - & 1.2 & 0.8 & 0.6 & 6 & 9 & 2 & 0.1 & & 1.1 & 0. & 0.1 & & & 3.2 \\
\hline & 0. & 0. & -1 & 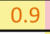 & 1 & 6 & 0.7 & 1.7 & 1.1 & 1.0 & 0.0 & 1.3 & 0.6 & .5 & 0.1 & 3 & 1.4 & 1.4 & 2 & 1.2 & 1.4 & 1.4 & 0.5 & 1.2 & 1.0 & 0.6 & 0. & & 1.5 & & .7 & & & 3.2 \\
\hline-28 & 0. & 0.3 & 5 & 0.4 & 0.7 & 0.1 & 0.4 & $\overline{0.9}$ & 1.0 & -1 & 0.0 & 5 & 0.6 & 5 & 0.0 & .4 & 1.5 & 1.1 & .0 & 0.4 & 1.2 & 1.1 & $\begin{array}{ll}0.4 \\
\end{array}$ & $\begin{array}{ll}0.7 \\
\end{array}$ & 0.8 & 0.0 & 0 & & 1.3 & 0. & 0.5 & & 54 & \\
\hline-41 & 0. & & 0.4 & - & 1.0 & 1.2 & 0.9 & 1.5 & 1.5 & 0.5 & 0.0 & 5 & 1 & 2 & 0.1 & 4 & 1.4 & - & 3 & 1 & 1.2 & 1.2 & 0.2 & 0.8 & $\begin{array}{l}1.1 \\
\end{array}$ & 0.1 & 0.1 & 0.4 & \begin{tabular}{|l}
1.4 \\
\end{tabular} & 0.2 & 0.7 & & 0.71 & 3.2 \\
\hline 47 & 0. & 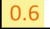 & ..J & \pm & 4 & $1+$ & 0.9 & 1.7 & 1.5 & 0.5 & 0.1 & 3 & 2 & 2 & 0.0 & 1.4 & 4 & 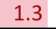 & 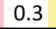 & 1.0 & 0.0 & 1.2 & 0.2 & .1 & 0.7 & 0.2 & & 1.2 & 2.1 & 0.2 & 0.8 & 0.5 & .89 & 3.2 \\
\hline-53 & 0.0 & 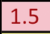 & 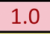 & 1.4 & 1.7 & 0.2 & 0.8 & 1.8 & 1.6 & 1.3 & 0.0 & 9 & 1.4 & 1.7 & \begin{tabular}{|l|}
0.0 \\
\end{tabular} & 1.3 & 1.6 & 1.9 & 0.3 & 1.7 & 1.3 & 1.2 & 0.3 & 1.2 & 1.4 & \begin{tabular}{|l|}
1.1 \\
\end{tabular} & 0.0 & 2.2 & 1.8 & 0.2 & 0.6 & 1.1 & 1.15 & 3.2 \\
\hline 60 & 0 & 0.8 & 0.6 & 0 & 1.0 & 0.2 & 0.8 & 1.6 & 1.3 & 0.4 & 0.0 & 1.5 & 0.7 & 1.5 & 0.0 & 9 & 1.3 & 1.7 & 0.4 & 1.0 & 1.8 & 1.3 & 0.1 & 1.1 & 1.2 & 0.1 & 0.1 & 0.2 & 1.8 & 0.2 & .6 & $0 . \varepsilon$ & 8.84 & 3.2 \\
\hline & 0. & 0.0 & 0.8 & 0.6 & 0.9 & 0.4 & 0.0 & 1.4 & 1.5 & 0.0 & 0.0 & 7 & 1.0 & 1.4 & 0.0 & 1.2 & 1.8 & 1.5 & 0.0 & 0.7 & 1.4 & .3 & 0.0 & 0.7 & 1.5 & 0.0 & 0.0 & 0.0 & 1.2 & 0.0 & 0.5 & & .68 & 2. \\
\hline & 0. & 1.0 & 0.8 & 1.1 & 1.0 & 0.9 & 0.7 & 1.8 & 1.3 & 1.6 & 0.1 & 1.7 & 1.8 & 1.5 & 0.1 & 1.4 & 1.4 & 1.4 & 0.2 & 1.7 & 1.6 & \begin{tabular}{|l}
1.3 \\
\end{tabular} & 0.5 & 1.4 & 1.2 & 0.7 & 0. & 1.1 & 1.8 & 0.2 & 1.3 & $0 . \varepsilon$ & 10 & 3.3 \\
\hline & 0. & 0.1 & 1 & 0.8 & 0.8 & 0.1 & 0.0 & 2.3 & 1.1 & 3 & 3 & 0.3 & 5 & .6 & 0.2 & .8 & 1.3 & & 0 & 1.6 & 1.5 & 0.8 & 0.2 & 3 & .2 & .0 & & & 1.5 & 0 & 0.2 & . & & \\
\hline & & & 1 & 0 & & 0.1 & 0.5 & 1.6 & 0.7 & & 0.1 & 9 & 0.4 & 5 & 0.1 & 1.4 & 1.4 & 1.3 & 1 & 1.0 & 1.3 & 1.2 & 0.1 & 0.7 & 1.2 & 0.6 & & & 1.4 & 0 & 0.4 & 0. & 59 & \\
\hline כ2 & 0 & & & 1 & 1.3 & 1 & 8 & 1.7 & 1.4 & & 0. & & b & & 0.0 & 6 & 7 & & 7 & & & & 0.1 & & 1.2 & 0.2 & & 2 & & & 1.3 & & 98 & \\
\hline & & & & & & & & & & & & & & & & .3 & 1.4 & & & 1.1 & 1.3 & & 0.3 & 1.0 & & 0.3 & 0.0 & 0.4 & & 0.1 & 0.7 & 0. & 0.8 & \\
\hline
\end{tabular}

Fig. 2. Average consumption on Day 11 (T15) of each compound with depth (cm) in aerobic and anaerobic conditions, with the $H^{\prime}$ and average well color development (AWCD) values. Color scale: white, without significant consumption (lower than 0.5); yellow, low consumption (between 0.5 and 1); light red, high consumption (between 1 and 1.5); dark red, very high consumption (upper 1.5); purple, highly consumed compound at all depths (average higher than 1); green, compound that did not show consumption (average lower than 0.3). A1: blank. See Fig. 1 for identity (color) of carbon sources

lower amounts of debris were present in the deeper part (authors' pers. obs.).

\section{Stratification}

The microbial metabolism, expressed as AWCD, varied between microplates incubated under aerobic and anaerobic conditions (Fig. 2). There was consumption of microbial substrates at all depths, but it was higher in the upper part of the mat (upper $34 \mathrm{~cm}$ ) for the aerobic compared to the anaerobic incubation (Student's $t$-test: $\mathrm{p}<0.001$, mean AWCD: aerobic 0.81 \pm 0.16 ; anaerobic $0.71 \pm 0.11$ ). In the deeper samples (below $34 \mathrm{~cm}$ ) anaerobic metabolism was higher than aerobic (Student's $t$-test: $\mathrm{p}<0.001$, mean AWCD: aerobic $0.55 \pm 0.12$; anaerobic $0.87 \pm 0.20$ ). For the whole core, anaerobic metabolism was higher than the aerobic (Student's $t$-test: $\mathrm{p}<0.001$, mean AWCD: aerobic $0.66 \pm 0.19$; anaerobic $0.80 \pm 0.18$ ).

The AWCD showed 2 distinct phases in all incubations, with a fast rate in the beginning (until T4 or T7 in aerobic incubations and T4 to T12 in anaerobic conditions) followed by a slower rate for the remaining part of the incubation period. The aerobic bacteria responded faster in the upper parts of the core, whereas the rates were similar for aerobic and anaerobic incubations in the deeper parts. The rates of the second phase were similar for both metabolisms and showed little variation with depth (Fig. 3).

The $H^{\prime}$ diversity index was very similar for both conditions and all the samples, averaging $3.1 \pm 0.1$.

\section{Compound consumption}

The carbon utilization was similar for aerobic and anaerobic metabolisms, but there were major differences between the substrates. A higher consumption (average color development of the carbon source in the whole core $>1$ ) was recorded in aerobic conditions for 3 amino acids, 4 carbohydrates, and 3 polymers (B4, C1, C4, D2, D4, E1, E2, F1, G1 and H1; Fig. 2), and in anaerobic conditions for 1 miscellaneous compound, 5 polymers, 5 carbohydrates, 4 amino acids, and 1 carboxylic acid (B1, B4, C1, C4, 

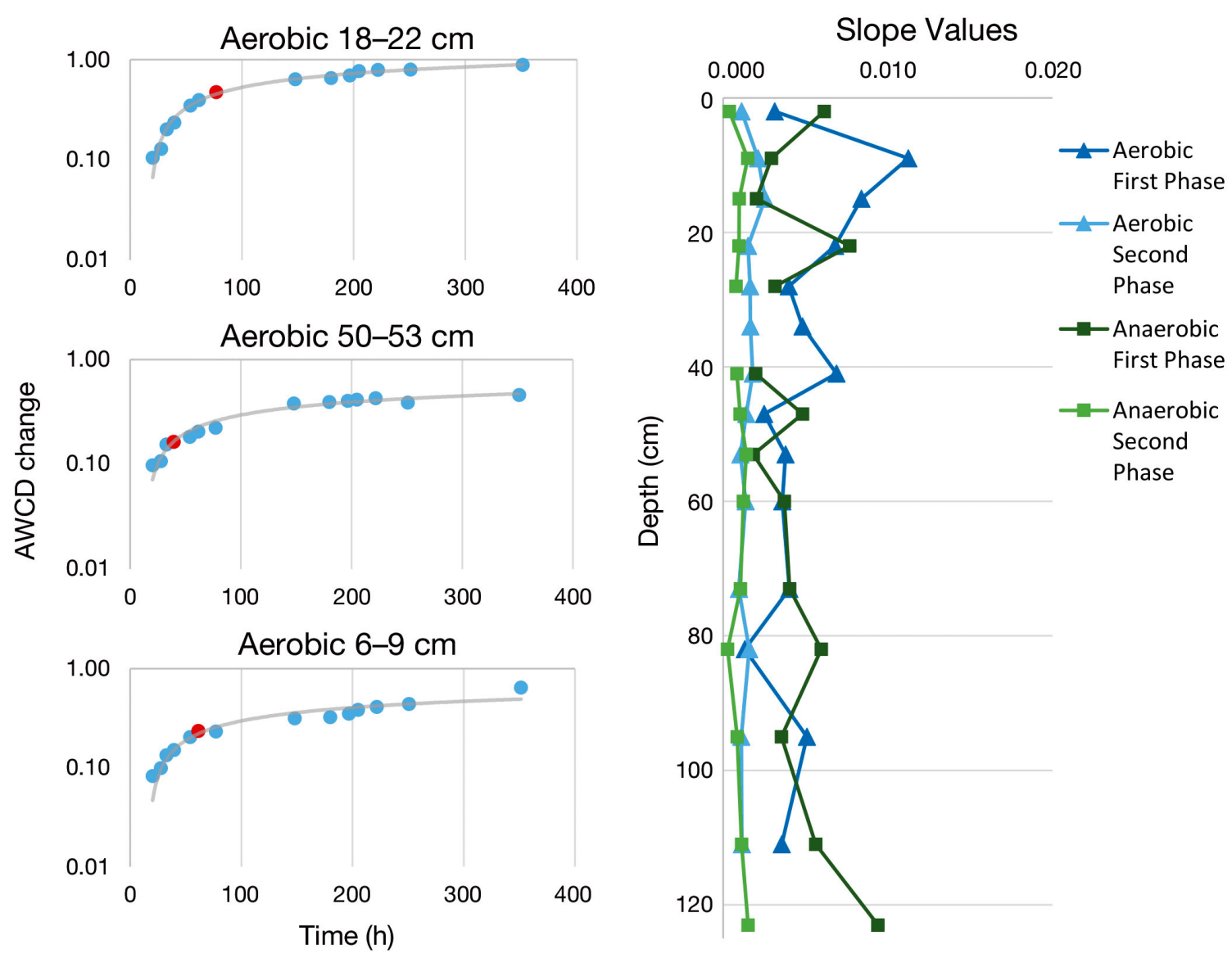

Fig. 3. Average well color development (AWCD) kinetics. Left panels: examples of AWCD change with time (logarithmic $y$ axis) at 3 depths $(6-9,18-22$ and 50-53 cm). Red dots indicate phase change; grey line shows logarithmic fitting curve. Right panel: distribution of the slope (carbon consumption rates) with depth

D1, D2, D4, E1, E2, E4, F1, F2, F4, G1 and H1; Fig. 2). There was no consumption (average color development $<0.3$ ) of 1 carbohydrate, 4 carboxylic acids and 2 miscellaneous (A2, C3, D3, E3, G2, G3 and H2; Fig. 2) in the aerobic incubation. Similarly, 5 carboxylic acids and 1 miscellaneous (C3, D3, E3, F3, G3 and $\mathrm{H} 2$; Fig. 2) were not consumed in the anaerobic incubation. The remaining compounds showed intermediate levels of consumption (aerobic: 5 carboxylic acids, 3 amino acids, 2 carbohydrates, 2 amines, 1 polymer and 1 miscellaneous compound; anaerobic: 3 carboxylic acids, 1 amino acid, 3 carbohydrates, 2 amines and 1 miscellaneous compound). The carbon guilds with highest consumption were polymers (aerobic average: $1.32 \pm 0.54$; anaerobic average: $1.23 \pm$ 0.34 ), carbohydrates (aerobic average: $0.96 \pm 0.58$; anaerobic average: $1.03 \pm 0.56$ ) and amino acids (aerobic average: $0.79 \pm 0.58$; anaerobic average: $1.17 \pm$ 0.42). Conversely, the carbon guilds with the lowest consumption were carboxylic acids (aerobic average: $0.32 \pm 0.30$; anaerobic average: $0.39 \pm 0.42$ ), amines (aerobic average: $0.45 \pm 0.26$; anaerobic average: $0.55 \pm 0.5$ ) and miscellaneous compounds (aerobic average: $0.37 \pm 0.45$; anaerobic average: $0.51 \pm 0.5$ ) .

The aerobic consumption of polymers was higher than the anaerobic in the first $40 \mathrm{~cm}$ (AN:AE < 1) whereas the opposite was the case below this depth (AN:AE > 1; Fig. 4). The carbohydrate consumption by both metabolisms followed a similar pattern to that of the polymers, with most of the AN:AE ratios lower than 1 in the top $40 \mathrm{~cm}$ and most of them above 1 below $40 \mathrm{~cm}$, and higher heterogeneity among the compounds. Amino acids were consumed at all depths, except for A4, E4 and F4, which showed no consumption under aerobic conditions in several samples (Fig. 4). The distribution with depth of the AN:AE ratio was more homogeneous in the first $40 \mathrm{~cm}$ (except for the top sample) and more heterogeneous and higher below. The carboxylic acids showed a low consumption for both metabolisms. The depth distribution of the $\mathrm{AN}$ :AE ratio was homogeneous with less data 
Anaerobic:Aerobic
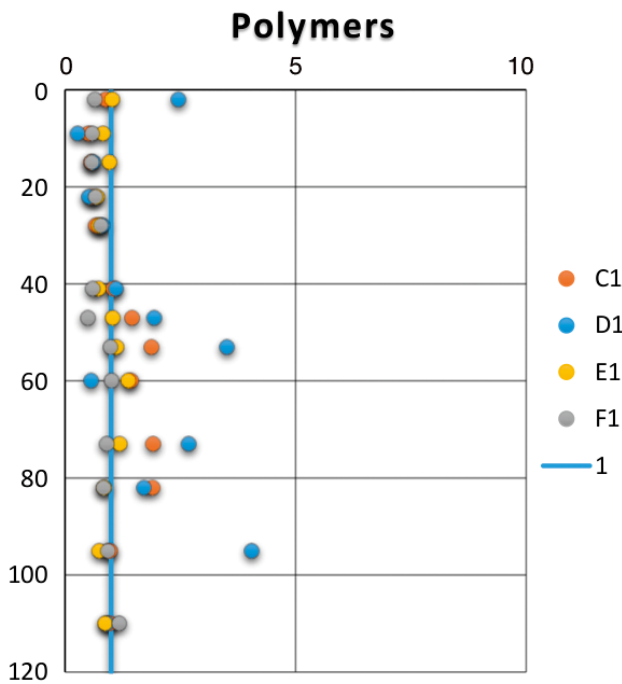

Carboxylic Acids
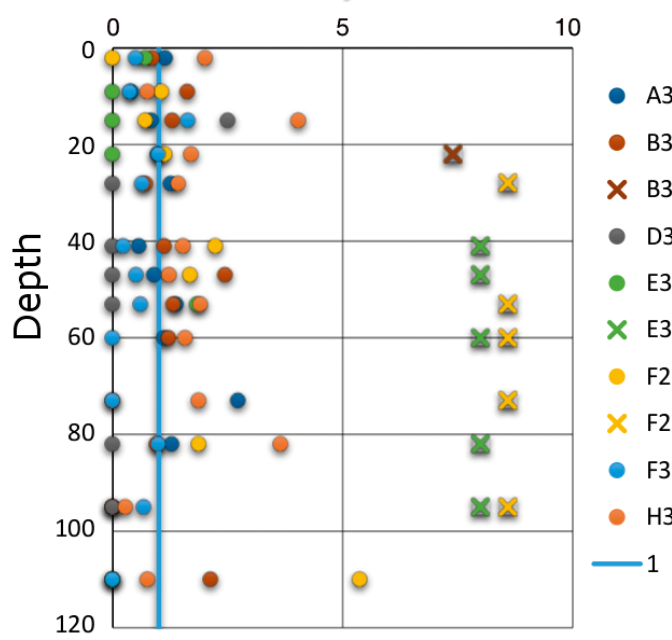

Amino Acids
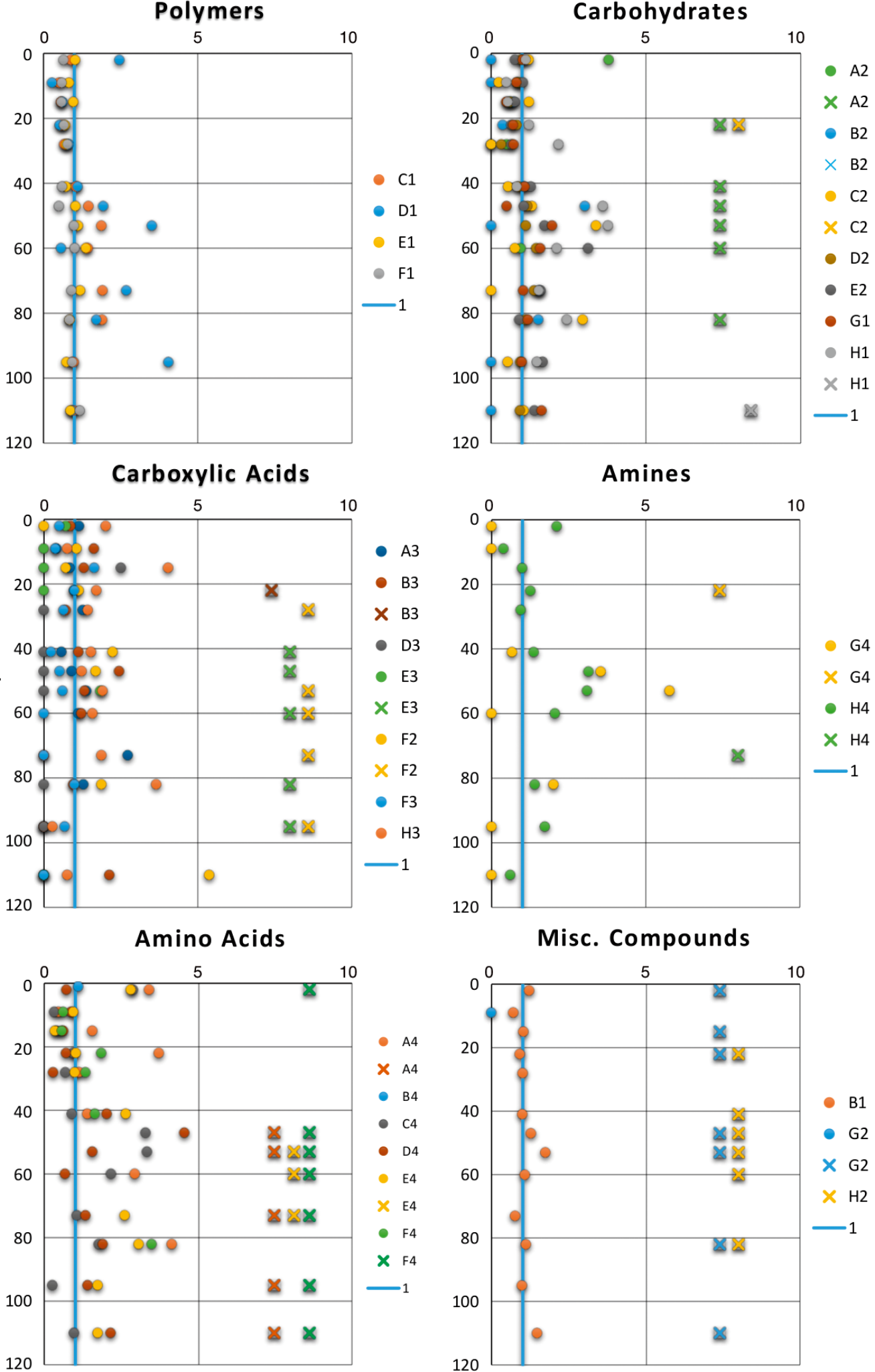

Amines

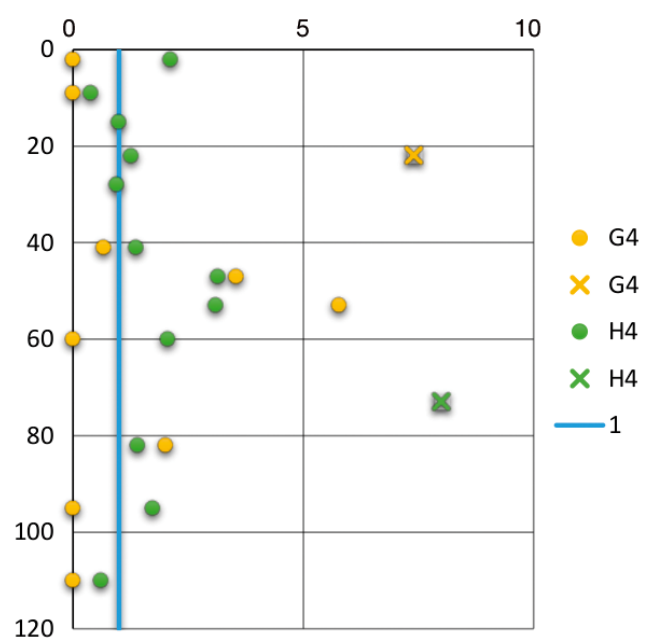

Misc. Compounds

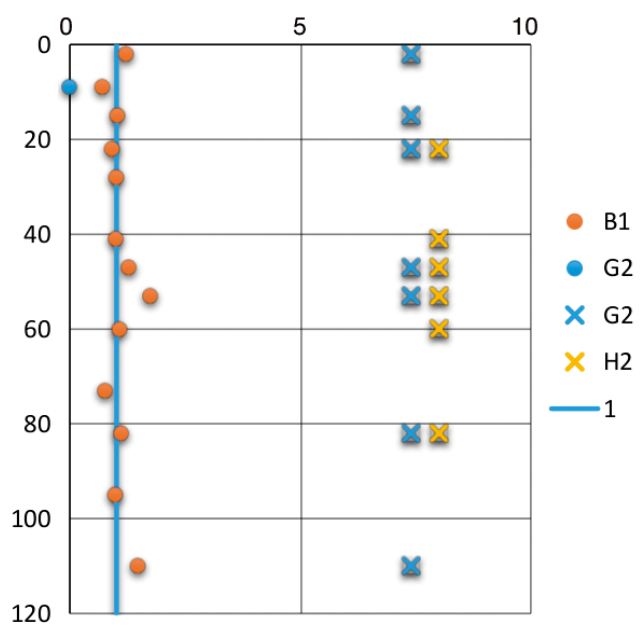

Fig. 4. Distribution of the anaerobic:aerobic ratio (AN:AE) of each EcoPlate carbon guild with depth (cm) at T15. Values on the $y$-axis indicate no significant anaerobic consumption; samples marked with an ' $\mathrm{X}$ ' indicate no significant aerobic consumption. The blue line indicates identical anaerobic and aerobic AWCD values. See Fig. 1 for identity of carbon sources 
available below $60 \mathrm{~cm}$ due to the lack of consumption by one of the metabolisms or both. The amines ratio showed a very heterogeneous distribution with no clear depth pattern. The miscellaneous compounds G2 and H2 were barely consumed under aerobic or anaerobic conditions. The miscellaneous B1 was consumed in both oxic and anoxic conditions at all depths showing a homogeneous rate distribution of around 1 .

\section{AWCD kinetics}

The AWCD value of each sample was calculated to the 15th time measurement, obtaining its change over time. The resulting curve fitted a logarithmic model where 2 phases could be differentiated: a first fast consumption phase and a second slower phase, with variation in the time of change between the 2 phases among samples.

The slope of the first phase was almost always higher than that of the slow consumption phase (Fig. 3). The average slope for the faster aerobic phase was $4.9 \times 10^{-3} \pm 2.6 \times 10^{-3}$, and for the slow phase $1.5 \times 10^{-3} \pm 0.4 \times 10^{-3}$. Under anaerobic conditions, the average slopes were $4.5 \times 10^{-3} \pm 2.3 \times$ $10^{-3}$ and $1.0 \times 10^{-3} \pm 0.4 \times 10^{-3}$, respectively. For the first phase, the aerobic and anaerobic consumption rates (i.e. slopes) were, respectively, 3.3 and 4.5 times higher on average than those of the second phase. In the first phase, average rates were quite similar for both metabolisms, while the aerobic metabolism was 1.5 times higher than the anaerobic for the second phase.

The depth distribution of consumption rates was similar for the aerobic metabolism $(\mathrm{r}=0.67, \mathrm{p}<0.01)$, with low values in the uppermost sample, the largest values in the next 2 to 3 samples and a decreasing trend below. No trend was found for the consumption rates of the 2 phases under anaerobic conditions.

\section{DISCUSSION}

Microbial functional activity was found for both aerobic and anaerobic metabolisms throughout the Posidonia oceanica $1.3 \mathrm{~m}$ soil core studied. The microbial consumption of the substrates was higher under anaerobic conditions and showed large differences between the carbon sources. Polymers, carbohydrates and amino acids were more readily used than carboxylic acids, amines or miscellaneous compounds.

\section{Stratification}

Substrate consumption evidences the presence of microorganisms able to metabolize carbon sources with and without oxygen, facultatively or strictly, in all samples studied. The degradation efficiency or the microbial density in the initial inoculum of aerobic microorganisms was probably higher in the topmost half of the core, where the degradation of the carbon sources was higher (Fig. 2). Conversely, in the bottom half of the core the efficiency/density of aerobic microorganisms was probably lower than that of anaerobic microorganisms, as average AWCD values for the whole core were 1.2 times higher for the anaerobic than for the aerobic experiment $(0.80$ vs. 0.66$)$, despite anaerobic metabolism being less efficient in carbon degradation (Fenchel et al. 1998). This suggests that the cell number of anaerobic microorganisms must have been larger to account for the higher activity. P. oceanica has adapted to the anoxic conditions of its soils by releasing oxygen through the roots to the sediment to maintain an oxic rhizosphere and avoid the formation and uptake of sulfides into the plant (Holmer et al. 2003, Borum et al. 2006). The average length of Posidonia spp. roots is approximately $43 \mathrm{~cm}$ (Duarte et al. 1998), justifying the occurrence of aerobic activity in this part of the sediments. Bioturbation is also a common process taking place in the upper layers of seagrass sediments resulting in an increased oxygenation (Kristensen 2000). Outside the influence of the rhizosphere or the bioturbated areas, the carbon consumption in the soil occurs through anaerobic metabolism. It seems then plausible to hypothesize that the main process of degradation of organic matter in the mat is the anaerobic metabolism, limiting the degradation of organic matter and thereby preserving plant remains, resulting in high accumulation of organic C, as previously observed (e.g. Serrano et al. 2012).

The $H^{\prime}$ index was high and similar for both metabolisms along the depth of the core, suggesting a diverse microbial community, similar to previous findings in $P$. oceanica meadows (García-Martínez et al. 2009, Säwström et al. 2016) and over terrestrial soils (Liao et al. 2016, Nurulita et al. 2016, Thomas et al. 2016).

\section{Substrate consumption}

The main difference between the 2 incubations that is related to consumption of carbon sources is the larger number of compounds with high consumption 
(average absorbance value through the whole core $>1$, Fig. 2) in the anaerobic incubations. Five compounds were metabolized to a greater extent in the anaerobic compared to the aerobic incubations, suggesting a wider spectrum of potential carbon sources for the anaerobic metabolism.

The polymers were metabolized easily by both metabolisms throughout the core. In the first $40 \mathrm{~cm}$, the ratio between anaerobic and aerobic metabolism remained below 1, meaning a higher aerobic potential activity on polymers. Below this depth, only F1 (glycogen) stayed $<1$, whereas other compounds, e.g. C1 and D1 (Tween 40 and 80), showed higher consumption under anaerobic conditions.

Like the polymers, the carbohydrates showed faster aerobic consumption in the first $40 \mathrm{~cm}$, and shifted to higher anaerobic consumption below. Some of the carbohydrates differed from this behavior: A2 ( $\beta$-methyl-D-glucoside) had limited aerobic consumption at almost all depths but it was moderately consumed under anaerobic conditions (Figs. $2 \& 4$ ); C3 (2-hydroxy benzoic acid) had low consumption under both conditions and did not present any clear trend; B1 showed high aerobic consumption in the first $40 \mathrm{~cm}$ and low in the remaining samples, but almost no anaerobic consumption.

All of the amino acids were highly consumed under anaerobic conditions, while they were only consumed in the first $40 \mathrm{~cm}$ under aerobic conditions, with particular low consumption of A4, E4 and F4 (Larginine, L-threonine and glycyl-L-glutamic acid). This seems to point towards an adapted anaerobic community with a wider spectrum of amino acids as substrates. The aerobic community in the upper sections would be expected to rely on leached organic matter from the roots, while the anaerobic community, growing away from the influence of the rhizosphere, may have access to more aged organic matter, developing metabolic pathways to degrade less labile carbon sources.

The carboxylic acids showed a very low consumption for both metabolisms throughout the core. The exception is F2 (D-glucosaminic acid), which only showed low consumption in the aerobic metabolism, while its consumption was one of the fastest under anaerobic conditions. D-glucosaminic acid is degraded by glucosaminic acid dehydrase, which is produced by microorganisms highly adapted to this carbon source (Balazs \& Jeanloz 1966). In accordance with our data, microorganisms with the potential to degrade glucosamine acids are primarily found under anaerobic conditions, with only moderate potential activity in the most superficial aerobic samples.

Amines and miscellaneous compounds showed low consumption in both metabolisms, except for B1 (pyruvic acid methyl ester).

The different behavior found for highly consumed carbon guilds (polymers, carbohydrates and amino acids) between the first $40 \mathrm{~cm}$ and the rest of the core seems to agree with the hypothesis that the rhizosphere influences the microbial community by changing oxygen availability around it, as mentioned above. The fact that these differences were not observed for the remaining 3 guilds can be due to their general lower potential consumption. As most of the dissolved organic matter, fresh plant remains and seston organic matter would be deposited on the first layers of the soil or on the rhizosphere, it seems reasonable to hypothesize that the resident anaerobic community has developed the capacity to feed on a wider spectrum of carbon sources (more amino acids and glucosaminic acids) to compensate for the lack of easy degradable ones. This hypothesis would be in agreement with the wider range of carbon sources highly utilized by the anaerobic metabolism (15 vs. 10).

Only a few compounds were not consumed in either of the 2 experiments ( 4 carboxylic acids and 1 miscellaneous compound; C3, D3, E3, G3 and H2). Furthermore, there was no consumption of A2 and G2 (carbohydrate and miscellaneous) under aerobic conditions and F3 (carboxylic acid) under anaerobic conditions. C3 and D3 (2- and 4-hydroxy benzoic acid) are abundant in P. oceanica detritus and associated with roots and sheaths, which form the plant debris that increases down through the core (Kaal et al. 2016). The lack of consumption of these carbon sources in our experiment supports the interpretation of Kaal et al. (2016) that they are part of a recalcitrant bigger compound, the stability of which prevents the microbial degradation associated with the humified materials in the fine fraction of the sediment (Gadel \& Bruchet 1987), avoiding the development of a microbial consumer community. Compounds without a community of consumers are good candidates to become blue carbon, even if the mechanisms of stabilization are not yet clear.

Similar studies, under aerobic conditions, found no consumption of one of the carboxylic acids (E3, $\gamma$ hydroxybutyric acid) and very low consumption of a miscellaneous compound (H2, D,L- $\alpha$-glycerol phosphate) in peat samples (Pérez Rodríguez \& Martínez Cortizas 2014); minimum consumption of amines, carboxylic acids and phenolic compounds (C3 and 
D3, here as carboxylic acids) in seagrass sediment cores from estuarine and coastal environments (Säwström et al. 2016); and very low consumption of G3 and C3 (both carboxylic acids) and, again, no consumption of E3, in a large set of soil samples (Rutgers et al. 2016), suggesting limited consumption of these carbon sources in soils.

\section{Kinetics}

Overall, the AWCD with incubation time fitted an asymptotic curve. Pérez-Rodríguez \& MartínezCortizas (2014) obtained similar patterns, interpreting them as sigmoidal, as is usually found in the literature on the topic. In our study, the lag phase leading to a sigmoidal pattern was not evident, as we did not record data for the first $2 \mathrm{~d}$. The slope of the phases, the fast growing phase and the slow phase reaching the asymptote, was used as a proxy of carbon consumption rate. The point of change between the 2 phases varied among samples but was always between 40 and $80 \mathrm{~h}$ under aerobic conditions and between 40 and $220 \mathrm{~h}$ under anaerobic conditions (Fig. 3). This wider range for anaerobic incubations can be related to a slower growth rate of the community (Fenchel et al. 1998, Kristensen \& Holmer 2001).

The second phase rate was quite similar for both metabolisms with no major variation along the depth of the core (Fig. 3). The first phase for anaerobic metabolisms was more heterogeneous without a particular trend. Conversely, the aerobic metabolism showed a maximum in the topmost $40 \mathrm{~cm}$ (especially 6 to 9 and 12 to $15 \mathrm{~cm}$ ), with lower values below. The higher rate can be related to a more efficient community or, more likely, to a higher initial cell number.

\section{CONCLUSIONS}

To our knowledge, EcoPlates have been used only once to test anaerobic consumption in water samples (Christian \& Lind 2006, 2007), but never in soil or sediment samples.

Applying the same protocol under aerobic and anaerobic conditions allows direct comparisons of the results to be made. It must be taken into account that the information about carbon source consumption provided by the EcoPlates has to be regarded as potential, because the conditions of the incubation are far from those in the field. Furthermore, growing microorganisms in the laboratory can affect the community structure promoting those more suited to growth in culture medium. Also, as EcoPlates are intended to analyze aerobic metabolism, the final electron acceptor of the respiration chain is $\mathrm{O}_{2}$, but when incubated under anaerobic conditions the electron acceptors available to the microorganisms must come from the initial inoculum. This can affect the results in 2 ways: the anaerobic acceptor may not be in excess, as assumed, and the initial inoculum may not have one of the possible electron acceptors (except $\mathrm{SO}_{4}$, which was provided in excess in the artificial seawater) present in the soil. This will result in a lower microbial activity. Despite these methodological limitations, we think that the following conclusions can be inferred from this study:

(1) Carboxylic acids and amines do not seem to be easily degraded by the Posidonia oceanica soil community. Further research is needed to determine if these compounds are preferentially preserved as recalcitrant forms. The anaerobic community seems to be able to metabolize a wider spectrum of carbon sources than its aerobic counterpart, and has adapted to feed on more recalcitrant compounds.

(2) Microbes show a clear depth stratification, most likely resulting from oxygen gradients associated with both the distance to the soil surface and to the roots of the seagrass. Two zones were identified: one near the living plant, where the fresh plant exudates and plant debris are actively decomposed, and a slow degradation zone, where the buried carbon decays slowly. Further experiments will be necessary to know if there is also a stratification within the anaerobic metabolism due to the other electron acceptors.

(3) Overall, our results point to a clear dominance of anaerobic metabolism in the seagrass soil samples studied. Consumption stratification and kinetic patterns strongly suggest that the community of anaerobes is larger (cell number) and more active (higher potential activity) in $P$. oceanica soils than that of their aerobic counterparts. This outcome enhances understanding of the low organic carbon turnover reported for $P$. oceanica soils.

It has to be kept in mind that this experiment was performed with samples from a single mat core. Owing to the high biogeochemical variability occurring in the $P$. oceanica mat, it is expected that the observations made here can vary considerably following different gradients (seasonality, bathymetry, water and plant trophic status, etc.). The presented results are to be considered as a test of the method to stimulate further efforts in deciphering the role of microbial activity in the carbon dynamics associated with this unique and largely unexplored compartment of seagrass meadows. 
Acknowledgements. The authors thank Marta Pérez Rodriguez and Dr. Xose Luis Otero Perez for their valuable laboratory assistance and Carmen Leiva Dueñas and Anna Thoran for the sample collection. This work was funded by the projects SUMILEN (CTM2013-47728-R, MINECO) and PALEOPARK (1104/2014). This is a paper from the Group of Benthic Ecology 2014 SGR 120.

\section{LITERATURE CITED}

Alcoverro T, Manzanera M, Romero J (2001) Annual metabolic carbon balance of the seagrass Posidonia oceanica: the importance of carbohydrate reserves. Mar Ecol Prog Ser 211:105-116

Ancora S, Bianchi N, Butini A, Buia MC, Gambi MC, Leonzio C (2004) Posidonia oceanica as a biomonitor of trace elements in the Gulf of Naples: temporal trends by lepidochronology. Environ Toxicol Chem 23:1093-1099

Balata D, Bertocci I, Piazzi L, Nesti U (2008) Comparison between epiphyte assemblages of leaves and rhizomes of the seagrass Posidonia oceanica subjected to different levels of anthropogenic eutrophication. Estuar Coast Shelf Sci 79:533-540

Balazs EA, Jeanloz RW (1966) The amino sugars: the chemistry and biology of compounds containing amino sugars. Academic Press, London

Ballesta L, Pergent G, Pasqualini V, Pergent-Martini C (2000) Distribution and dynamics of Posidonia oceanica beds along the Albères coastline. C R Acad Sci III 323: 407-414

Borum J, Sand-Jensen K, Binzer T, Pedersen O, Greve TM (2006) Oxygen movement in seagrasses. In: Larkum AWD, Orth RJ, Duarte CM (eds) Seagrasses: biology, ecology and conservation. Springer, Dordrecht, p 255-270

Campagne CS, Salles JM, Boissery P, Deter J (2015) The seagrass Posidonia oceanica: ecosystem services identification and economic evaluation of goods and benefits. Mar Pollut Bull 97:391-400

Canfield DE (1994) Factors influencing organic carbon preservation in marine sediments. Chem Geol 114: 315-329

Christian BW, Lind OT (2006) Key issues concerning Biolog use for aerobic and anaerobic freshwater bacterial community-level physiological profiling. Int Rev Hydrobiol 91:257-268

* Christian BW, Lind OT (2007) Multiple carbon substrate utilization by bacteria at the sediment-water interface: Seasonal patterns in a stratified eutrophic reservoir. Hydrobiologia 586:43-56

Danovaro R, Fabiano M, Boyer M (1994) Seasonal changes of benthic bacteria in a seagrass bed (Posidonia oceanica) of the Ligurian Sea in relation to origin, composition and fate of the sediment organic matter. Mar Biol 119: 489-500

* De Falco G, De Muro S, Batzella T, Cucco A (2011) Carbonate sedimentation and hydrodynamic pattern on a modern temperate shelf: the strait of Bonifacio (western Mediterranean). Estuar Coast Shelf Sci 93:14-26

₹ Duarte CM, Merino M, Agawin NSR, Uri J and others (1998) Root production and belowground seagrass biomass. Mar Ecol Prog Ser 171:97-108

Fenchel T, King GM, Blackburn H (1998) Bacterial biogeochemistry: the ecophysiology of mineral cycling, 3rd edn. Elsevier, San Diego
Foden J, Brazier DP (2007) Angiosperms (seagrass) within the EU water framework directive: a UK perspective. Mar Pollut Bull 55:181-195

Freixa A, Rubol S, Carles-Brangarí A, Fernàndez-Garcia D, Butturini A, Sanchez-Vila X, Romaní AM (2016) The effects of sediment depth and oxygen concentration on the use of organic matter: an experimental study using an infiltration sediment tank. Sci Total Environ 540: 20-31

Gacia E, Duarte CM (2001) Sediment retention by a Mediterranean Posidonia oceanica meadow: the balance between deposition and resuspension. Estuar Coast Shelf Sci 52:505-514

Gadel F, Bruchet A (1987) Application of pyrolysis-gas chromatography-mass spectrometry to the characterization of humic substances resulting from decay of aquatic plants in sediments and waters. Water Res 21:1195-1206

* García-Martínez M, López-López A, Calleja ML, Marbà N, Duarte CM (2009) Bacterial community dynamics in a seagrass (Posidonia oceanica) meadow sediment. Estuaries Coasts 32:276-286

Garland JL, Mills L (1991) Classification and characterization of heterotrophic microbial communities on the basis of patterns of community-level sole-carbon-source utilization. Appl Environ Microbiol 57:2351-2359

Glazebrook PW, Moriarty DJW, Hayward A, MacRae IC (1996) Seasonal changes in numbers and the location of a particular bacterial strain of Alteromonas sp. in seagrass sediments. Microb Ecol 31:1-13

Glew JR, Smol JP, Last WM (2001) Sediment core collection and extrusion. In: Last WM, Smol JP (eds) Tracking environmental change using lake sediments. Vol 1: Basin analysis, coring, and chronological techniques. Kluwer Academic Publishers, Dordrecht, p 73-105

*Gobert S, Sartoretto S, Rico-Raimondino V, Andral B, Chery A, Lejeune P, Boissery P (2009) Assessment of the ecological status of Mediterranean French coastal waters as required by the Water Framework Directive using the Posidonia oceanica Rapid Easy Index: PREI. Mar Pollut Bull 58:1727-1733

*Holmer M, Duarte CM, Marbá N (2003) Sulfur cycling and seagrass (Posidonia oceanica) status in carbonate sediments. Biogeochemistry 66:223-239

Kaal J, Serrano O, Nierop KGJ, Schellekens J, Martínez Cortizas A, Mateo MÁ (2016) Molecular composition of plant parts and sediment organic matter in a Mediterranean seagrass (Posidonia oceanica) mat. Aquat Bot 133: $50-61$

Kristensen E (2000) Organic matter diagenesis at the oxic/anoxic interface in coastal marine sediments, with emphasis on the role of burrowing animals. Hydrobiologia 426:1-24

Kristensen E, Holmer M (2001) Decomposition of plant materials in marine sediment exposed to different electron acceptors $\left(\mathrm{O}_{2}, \mathrm{NO}_{3}{ }^{-}\right.$and $\left.\mathrm{SO}_{4}{ }^{2-}\right)$, with emphasis on substrate origin, degradation kinetics, and the role of bioturbation. Geochim Cosmochim Acta 65:419-433

Kristensen E, Ahmed SI, Devol AH (1995) Aerobic and anaerobic decomposition of organic matter in marine sediment: which is fastest? Limnol Oceanogr 40: 1430-1437

Liao N, Li Q, Zhang W, Zhou G and others (2016) Effects of biochar on soil microbial community composition and activity in drip-irrigated desert soil. Eur J Soil Biol 72: $27-34$ 
Llobet-Brossa E, Rabus R, Böttcher ME, Könneke M and others (2002) Community structure and activity of sulfatereducing bacteria in an intertidal surface sediment: a multi-method approach. Aquat Microb Ecol 29:211-226

Lo Iocano C, Mateo MA, Grácia E, Guasch L and others (2008) Very high-resolution seismo-acoustic imaging of seagrass meadows (Mediterranean Sea): implications for carbon sink estimates. Geophys Res Lett 35:1-5

López NI, Duarte CM, Vallespinós F, Romero J, Alcoverro T (1995) Bacterial activity in NW Mediterranean seagrass (Posidonia oceania) sediments. J Exp Mar Biol Ecol 187: 39-49

* López NI, Duarte CM, Vallespinós F, Romero J, Alcoverro T (1998) The effect of nutrient additions on bacterial activity in seagrass (Posidonia oceanica) sediments. J Exp Mar Biol Ecol 224:155-166

* López-Merino L, Serrano O, Adame MF, Mateo MÁ, Martínez Cortizas A (2015) Glomalin accumulated in seagrass sediments reveals past alterations in soil quality due to land-use change. Global Planet Change 133: 87-95

Kópez-Sáez JA, López-Merino L, Mateo MÁ, Serrano Ó, Pérez-Díaz S, Serrano L (2009) Palaeoecological potential of the marine organic deposits of Posidonia oceanica: a case study in the NE Iberian Peninsula. Palaeogeogr Palaeoclimatol Palaeoecol 271:215-224

Luy N, Gobert S, Sartoretto S, Biondo R, Bouquegneau JMM, Richir J (2012) Chemical contamination along the Mediterranean French coast using Posidonia oceanica (L.) Delile above-ground tissues: a multiple trace element study. Ecol Indic 18:269-277

* Lyons MM, Dobbs FC (2012) Differential utilization of carbon substrates by aggregate-associated and waterassociated heterotrophic bacterial communities. Hydrobiologia 686:181-193

Marbá N, Holmer M, Gacia E, Barrón C (2006) Seagrass beds and coastal biogeochemistry. In: Larkum AWD, Orth RJ, Duarte CM (eds) Seagrasses: biology, ecology and conservation. Springer, Dordrecht, p 133-155

Mateo MA, Romero J (1997) Detritus dynamics in the seagrass Posidonia oceanica: elements for an ecosystem carbon and nutrient budget. Mar Ecol Prog Ser 151:43-53

Mateo MA, Cebrián J, Dunton K, Mutchler T (2006) Carbon flux in seagrass ecosystems. In: Larkum AWD, Orth RJ, Duarte CM (eds) Seagrasses: biology, ecology and conservation. Springer, Dordrecht, p 159-192

Nurulita Y, Adetutu EM, Gunawan H, Zul D, Ball AS (2016) Restoration of tropical peat soils: the application of soil microbiology for monitoring the success of the restoration process. Agric Ecosyst Environ 216:293-303

* Pasqualini V, Pergent-Martini C, Clabaut P, Pergent G (1998) Mapping of Posidonia oceanica using aerial photographs and side scan sonar: application off the Island of Corsica (France). Estuar Coast Shelf Sci 47:359-367

Pedersen MØ, Serrano O, Mateo MÁ, Holmer M (2011) Temperature effects on decomposition of a Posidonia oceanica mat. Aquat Microb Ecol 65:169-182

Pérez Rodríguez M, Martínez Cortizas A (2014) Preliminary characterization of microbial functional diversity using sole-C-source utilization profiles in Tremoal do Pedrido mire (Galicia, NW Spain). Spanish J Soil Sci 4:158-178

* Pergent-Martini C, Leoni V, Pasqualini V, Ardizzone GD and others (2005) Descriptors of Posidonia oceanica meadows: use and application. Ecol Indic 5:213-230

* Pierce ML, Ward JE, Dobbs FC (2014) False positives in Biolog EcoPlates ${ }^{\mathrm{TM}}$ and MT2 MicroPlates ${ }^{\mathrm{TM}}$ caused by calcium. J Microbiol Methods 97:20-24
Richir J, Gobert S (2014) A reassessment of the use of Posidonia oceanica and Mytilus galloprovincialis to biomonitor the coastal pollution of trace elements: new tools and tips. Mar Pollut Bull 89:390-406

* Richir J, Velimirov B, Poulicek M, Gobert S (2012) Use of semi-quantitative kit methods to study the heterotrophic bacterial community of Posidonia oceanica meadows: limits and possible applications. Estuar Coast Shelf Sci 109:20-29

Richir J, Luy N, Lepoint G, Rozet E, Alvera Azcarate A, Gobert S (2013) Experimental in situ exposure of the seagrass Posidonia oceanica (L.) Delile to 15 trace elements. Aquat Toxicol 140-141:157-173

* Rodríguez-Valera F (2004) Environmental genomics, the big picture? FEMS Microbiol Lett 231:153-158

* Rutgers M, Wouterse M, Drost SM, Breure AM and others (2016) Monitoring soil bacteria with community-level physiological profiles using Biolog ${ }^{\mathrm{TM}}$ ECO-plates in the Netherlands and Europe. Appl Soil Ecol 97:23-35

* Säwström C, Serrano O, Rozaimi M, Lavery PS (2016) Utilization of carbon substrates by heterotrophic bacteria through vertical sediment profiles in coastal and estuarine seagrass meadows. Environ Microbiol Rep 8:582-589

* Serrano O, Mateo MA, Renom P, Julià R (2012) Characterization of soils beneath a Posidonia oceanica meadow. Geoderma 185-186:26-36

* Serrano O, Martínez-Cortizas A, Mateo MA, Biester H, Bindler R (2013) Millennial scale impact on the marine biogeochemical cycle of mercury from early mining on the Iberian Peninsula. Global Biogeochem Cycles 27:21-30

* Serrano O, Davis G, Lavery PS, Duarte CM and others (2016) Reconstruction of centennial-scale fluxes of chemical elements in the Australian coastal environment using seagrass archives. Sci Total Environ 541:883-894

Smith AC, Kostka JE, Devereux R, Yates DF (2004) Seasonal composition and activity of sulfate-reducing prokaryotic communities in seagrass bed sediments. Aquat Microb Ecol 37:183-195

* Sørensen KB, Glazer B, Hannides A, Gaidos E (2007) Spatial structure of the microbial community in sandy carbonate sediment. Mar Ecol Prog Ser 346:61-74

* Stefanowicz AM, Niklinska M, Kapusta P, Szareklukaszewska G (2010) Pine forest and grassland differently influence the response of soil microbial communities to metal contamination. Sci Total Environ 408: 6134-6141

* Thamdrup B, Rossello-Mora R, Amann R (2000) Microbial manganese and sulfate reduction in Black Sea shelf sediments. Appl Environ Microbiol 66:2888-2897

* Thomas F, Lorgeoux C, Faure P, Billet D, Cébron A (2016) Isolation and substrate screening of polycyclic aromatic hydrocarbon degrading bacteria from soil with long history of contamination. Int Biodeterior Biodegradation 107:1-9

Tovar-Sánchez A, Serón J, Marbà N, Arrieta JM, Duarte CM (2010) Long-term records of trace metal content of western Mediterranean seagrass (Posidonia oceanica) meadows: natural and anthropogenic contributions. J Geophys Res 115:1-10

* Tranchina L, Miccichè S, Bartolotta A, Brai M, Mantegna RN (2005) Posidonia oceanica as a historical monitor device of lead concentration in marine environment. Environ Sci Technol 39:3006-3012

Vassallo P, Paoli C, Rovere A, Montefalcone M, Morri C, Bianchi CN (2013) The value of the seagrass Posidonia oceanica: a natural capital assessment. Mar Pollut Bull $75: 157-167$ 